\title{
Evidence of mud diapirism and coral colonies in the Ionian Sea (Central Mediterranean) from high resultion chirp sonar survey
}

\author{
Nicoletta Fusi, Alessandra Savini and Cesare Corselli \\ Dipartimento di Scienze Geologiche e Geotecnologiche, \\ Università di Milano «Bicocca», Milano, Italy
}

\begin{abstract}
A chirp sonar survey in the Ionian Sea investigated the Calabrian margin, the Calabrian accretionary wedge, the Taranto Trench and the Apulian foreland. Shallow tectonic structures have been related to deeper ones, recognised on CROP seismic profiles. The identified echo characters have been compared with those described in the modern literature and have been related to different kinds of sediments, on the basis of core samples. Based on echo character and morphology we have recognised: 1) A widespread presence of mounds, up to $50 \mathrm{~m}$ high, occurring on the Apulian plateau as isolated mounds in the deepest zones (1600-800 m) and in groups in the shallower ones $(800-600 \mathrm{~m})$; they have been interpreted as coral mounds, according to a recent discovery of living deep water coral colonies in this zone. 2) Some mud diapirs, isolated or in groups of two or three elements, widespread in the whole study area. Similar to what has been observed on the Mediterranean ridge, their presence suggests the activity of deep tectonic structures (thrusts and faults) and a reduced thickness (or absence) of Messinian evaporites in this part of the Ionian Sea.
\end{abstract}

Key words Ionian Sea - chirp sonar - echo character - coral mound - mud volcano

\section{Introduction and geological setting}

In March 2002 a cruise onboard the R/V Urania, collected about $1100 \mathrm{~km}$ of Chirp 2 sonar profiles in the Ionian Sea, from the inner parts of the Calabrian Arc accretionary prism to the Apulian foreland, crossing the Taranto Trench (fig. 1). Part of the chirp data were collected along a trackline which follows CROP

Mailing address: Dr. Nicoletta Fusi, Dipartimento di Scienze Geologiche e Geotecnologiche, Università di Milano «Bicocca», Piazza della Scienza, 4, 20126 Milano, Italy: e-mail: nicoletta.fusi@unimib.it seismic line M5, oriented SW-NE (Doglioni et al., 1999; Merlini et al., 2000). A chirp sonar grid has been acquired off-shore Puglia, where living deep water corals (n.d.r. Lophelia pertusa) have been recently dredged (Tursi and Mastrototaro, pers. comm.).

According to several authors (Gasparini et al., 1982; Cristofolini et al., 1985; Malinverno and Ryan, 1986; Royden et al., 1987; Patacca and Scandone, 1989; Boccaletti et al., 1990; Doglioni et al., 1994, 1996; Selvaggi and Chiarabba, 1995) the Apennines belt is the result of the eastward retreat of the Adriatic-Ionian litosphere, during the last $30 \mathrm{Ma}$. The Southern Apennines and Calabria, located in the most arcuate part of the belt, migrated eastward at the fastest rates (about 3-4 cm/yr, Patacca and Scandone, 1989; Patacca et al., 1990; Doglioni, 1991). 


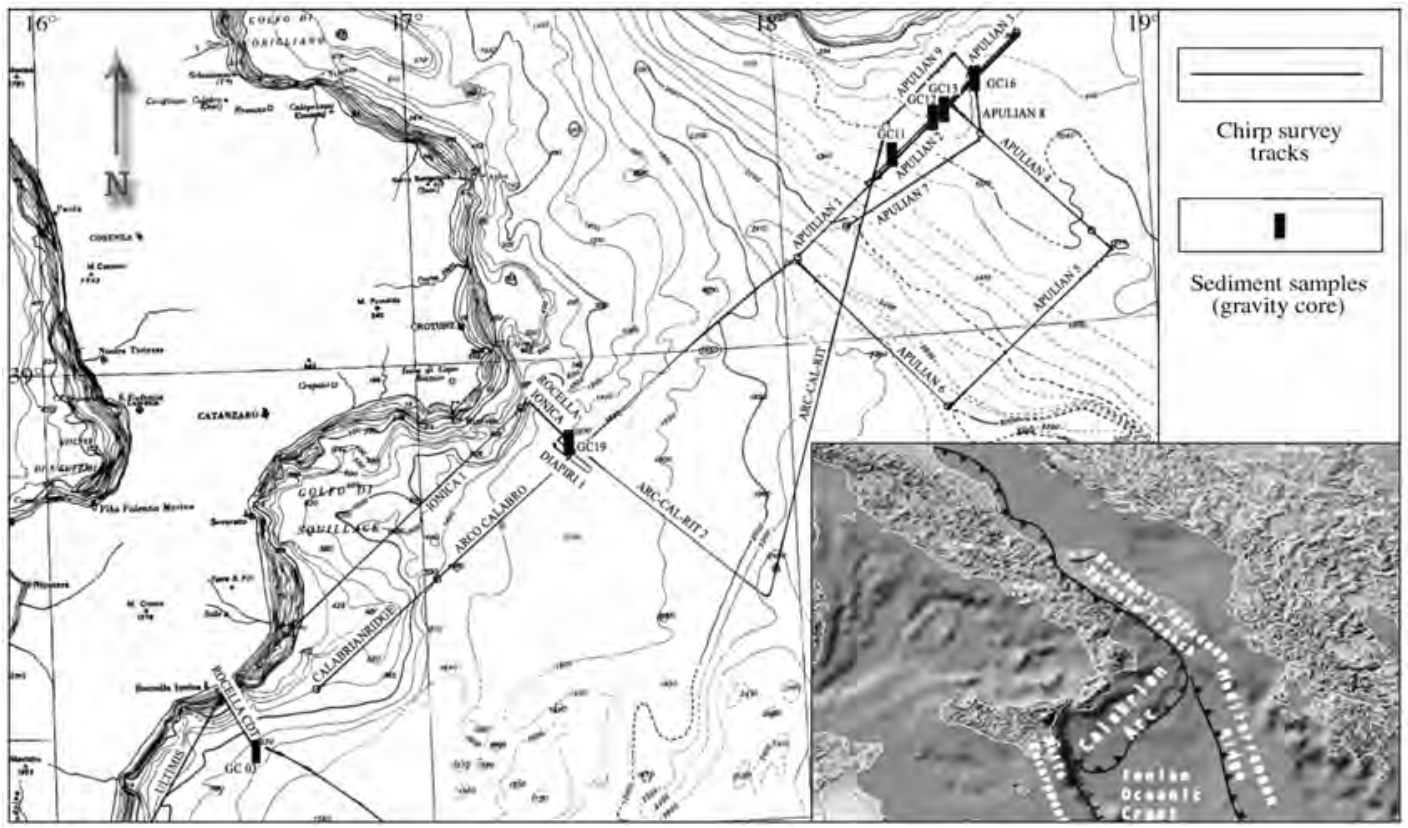

Fig. 1. Map of Northern Ionian Sea, showing the chirp lines and the main core locations, obtained during the Urania cruise, with the main structural tectonics elements of the Central Mediterranean region shown in the right down corner.

The Apennine belt consists of thrust sheets of the sedimentary cover (Mostardini and Merlini, 1986; Sella et al., 1988; Patacca and Scandone, 2004), later cross-cut by deep normal faults, along which fluids migrate upwards (Doglioni et al., 1996). The Southern Apennines belt is marked by compressive thin-skinned tectonics at the front and to the east and extensional thick-skinned tectonics in the main chain and to the west of it (Merlini et al., 2000).

Seismic line M5, underlying our chirp survey, runs from off-shore Eastern Calabria to off-shore Southern Puglia and is considered one of most representative lines of the Italian project CROP (Doglioni et al., 1999). On the Calabrian margin this section crosses extensional faults, which inland are well known to form grabens (Val d'Agri, Vallo di Diano; Merlini et al., 2000) and are responsible for the high seismicity of the Southern Apennines (Amato and Selvaggi, 1993); on the eastern side the section crosses the Apulian swell which appears rather as a $100 \mathrm{~km}$ wide buckling anticline, deforming the entire lithosphere (Merlini et al., 2000).

Objectives of our study are: 1) to identify the main shallow active tectonic structures; 2) to integrate these structures into the regional framework, defined by deeper seismics (CROP seismic line $M 5$ ); 3) to eventually relate regional fluid flow with the presence of living coral colonies and with active tectonics.

\section{Methods}

The chirp survey was carried out using the ship's DATASONIC DSP-661 Chirp 2 Profiler. Trigger rates varied from 2 to $4 \mathrm{~s}$, depending on water depth, ranging from about $600 \mathrm{~m}$ to about $2500 \mathrm{~m}$; the spectrum of frequencies of sound signal is between 3 to $7 \mathrm{kHz}$. The chirp survey was carried at a rather constant speed of about 10 knots, except for the lines on the Apulian 
plateau, where our main interest concentrated, which where carried at a lower speed of 4 knots.

Data were displayed on an EPC 9800 and recorded on Magneto-optical disks in SEG-Y format, with the exception of the first part of line Calabrian ridge, which was not recorded due to technical problems. Synchronization of this instrument with the navigation system (NAVPRO) allows precise location of structures on chirp profiles and precise localization for core sampling sites (gravity cores, fig. 1). Sediment samples were collected with a $10 \mathrm{~cm}$ diameter gravity corer at 6 stations (fig. 1); data from multi-corer, used mainly for biological interest, were also taken into account.

The digital chirp data were initially processed with suitable software to provide a useful image with proper geographic locations of features identified in the imagery. The processing steps included the replying data in several different vertical distance range windows, applying image corrections and digitising sub-bottom. The imagery was then visualised in its proper geographic location and exported from the software package as TIFF images with associated georeference information.

The chirp profiles yield a detailed image of the surficial structure up to $100 \mathrm{~ms}$ twt (corresponding to $80 \mathrm{~m}$ of sediments, using an interval velocity of $1600 \mathrm{~m} / \mathrm{s}$ ) depending on seafloor dip and characteristics. The interpretation of seismic facies identified on chirp profiles was compared with those identified by other authors (Damuth and Hayes, 1977; Damuth, 1980; Lee et al., 2002) and ground truth by means of core logs.

\section{Results and discussion}

The chirp survey (fig. 1) crosses the following structural domains, from SW to NE: the Calabrian margin, the accretionary wedge, the Taranto Trench and the Apulian foreland.

The seismic section identified by means of chirp profiling can be referred to Plio-Pleistocene units on the Calabrian margin, the accretionary wedge and the Taranto Trench, whereas on the Apulian plateau Neogene - Pleistocene units outcrop, forming the Apulian swell; for stratigraphic and structural interpretation of CROP seismic line M5 we refer to Doglioni et al. (1999) and Merlini et al. (2000). Seismic facies were related, if possible, to echo types identified by Lee $e t$ al. (2002) and indicated following their nomenclature (roman number + arabic one).

\subsection{Calabrian margin}

In this area the Chirp 2 system has generally a good penetration, ranging from 50 to $75 \mathrm{~ms}$ twt. The seismic sequence is characterised by strong reflectors alternating with transparent intervals, which mantle the topography, pinching out on the top of topographic highs. Prevalent echo type of this area can be attributed to type I-2.

This part of the seismic section is characterised by widespread dip-slip faults, which offset the seafloor for several hundred meters, the total throw of the Calabrian margin being of about $1500 \mathrm{~m}$. These faults cross-cut both the Plio-Quaternary sedimentary successions and the buried pre-Messinian back-thrusts (see fig. 3 of Merlini et al., 2000); their activity seems thus to be Plio-Quaternary. This active tectonics results in an articulated topography, with several horsts (off-shore Punta Stilo and Rocella Ionica) mantled by sediments (fig. 2).

The steepest flanks of horst structures (about $1.5^{\circ}$ gradient) are affected by mass movements: landslide scarps, about $20 \mathrm{~m}$ high, can be identified, due to sharply truncated reflectors. Landslide deposits, with chaotic reflectors inside, (type IV-1) extend for about $8.5 \mathrm{~km}$, both on the lower part of the slope and in the basin. Landslides seem to involve only the superficial and probably unconsolidated part of the sedimentary succession.

Several deeply incised canyons (fig. 2) are probably related to the outlet of nearby rivers. Off-shore Punta Stilo south-eastward dipping reflectors (fig. 3) are truncated by an erosional surface at about $150 \mathrm{~m}$ depth. A subhorizontal erosional surface, mantled by reflectors and probably related to the last glacial lowstand, can also be identified in this area at about $80-100 \mathrm{~m}$ b.s.l.

At least two non reflective mounds, 100$150 \mathrm{~m}$ high and $2500 \mathrm{~m}$ across, can be identified in this area, off-shore Rocella Ionica; multi-corer, put down twice on the top of one of 


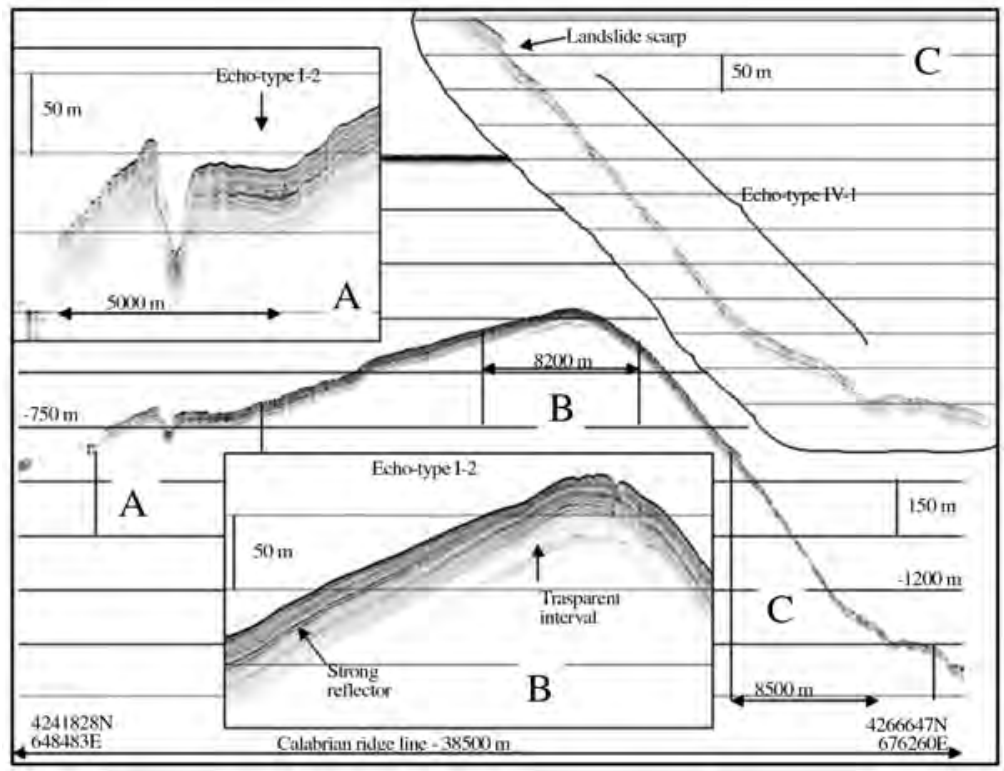

Fig. 2. Chirp profile across the Calabrian ridge (Calabrian ridge line - see fig. 1 for location), with the insets of the main structural features identified (A, B, C). A - example of a canyon; B - onlapping reflectors on the top of a horst; $\mathrm{C}$ - landslide scarp on the steepest flanks of horst structures and relative deposits.

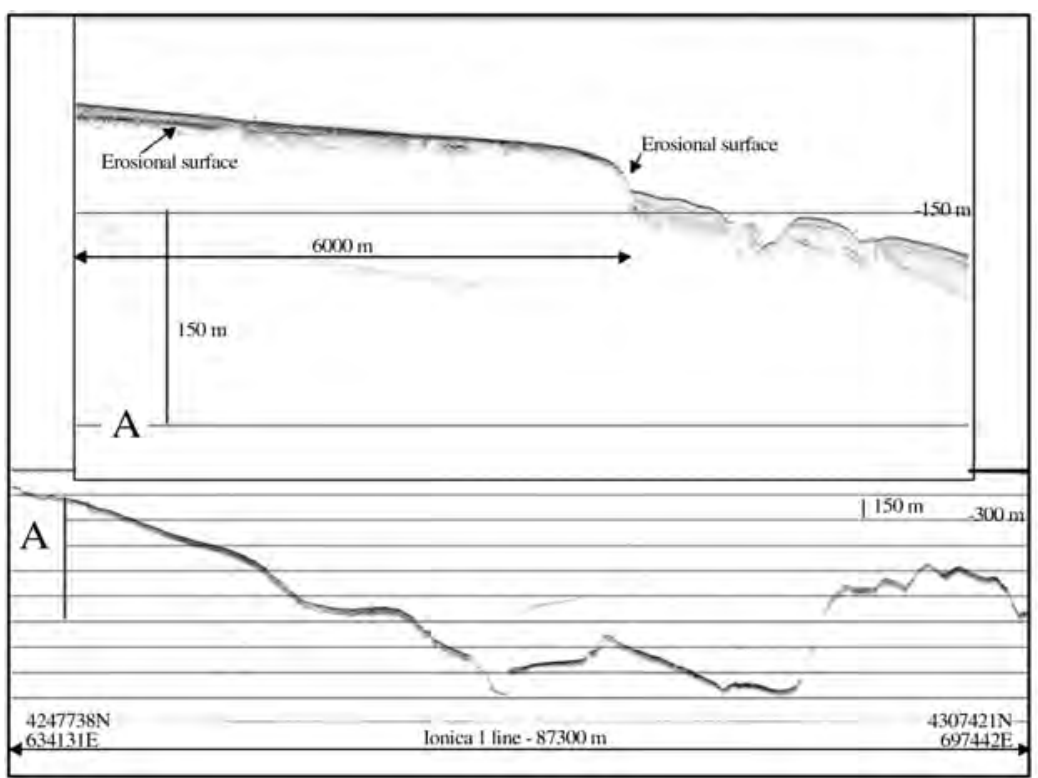

Fig. 3. Chirp profile across the Calabrian ridge and the western section of calabrian margin (Ionica 1 line - see fig. 1 for location). The zoom (A) shows the subhorizontal erosional surface of the shelf break, mantled by reflectors and probably related to last glacial lowstand at about $80-100 \mathrm{~m}$ b.s.l. 
these mounds, recovered no sediments at all, thus confirming the total lack of soft sediments on the top of the mounds. On the basis of seismic response and morphology they are interpreted as mud volcanoes.

\subsection{Accretionary wedge}

The accretionary wedge is characterised by a rough topography, ranging between $1400 \mathrm{~m}$ and $2000 \mathrm{~m}$ depth. The shallow sediments are gently deformed by symmetrical and asymmetrical waves, referred to echo type III-3 and interpreted as the result of creeping on the slope of the accretionary wedge; some patches of debrites (echo type III-2) are also present. Steep flanks are characterised by slumps (fig. 4).
A distinctive character of this area is a flat plateau, delineated by $1600 \mathrm{~m}$ and $1800 \mathrm{~m}$ isobaths and gently dipping south-eastward $\left(0.2^{\circ}\right)$, here called Punta Stilo plateau (fig. 4). It is characterised by an abrupt change in seismic character: the sea bottom is highly reflective and reflects nearly all the acoustic energy; only occasionally very few reflectors can be identified below sea bottom (echo type I-1). Micro undulations of the sea bottom of this plateau (echo type III-2) are visible only on Arco Calabro line (SE-NW). Punta Stilo plateau is interpreted as the outcropping of more resistant lithologies. We suggest that these lithologies are coarse grained turbidites, on the basis of «Rocella» core, which recovered several meters of mud intercalated with sandy layers; this interpretation is supported by other seismic surveys in this area, which outline the pinching

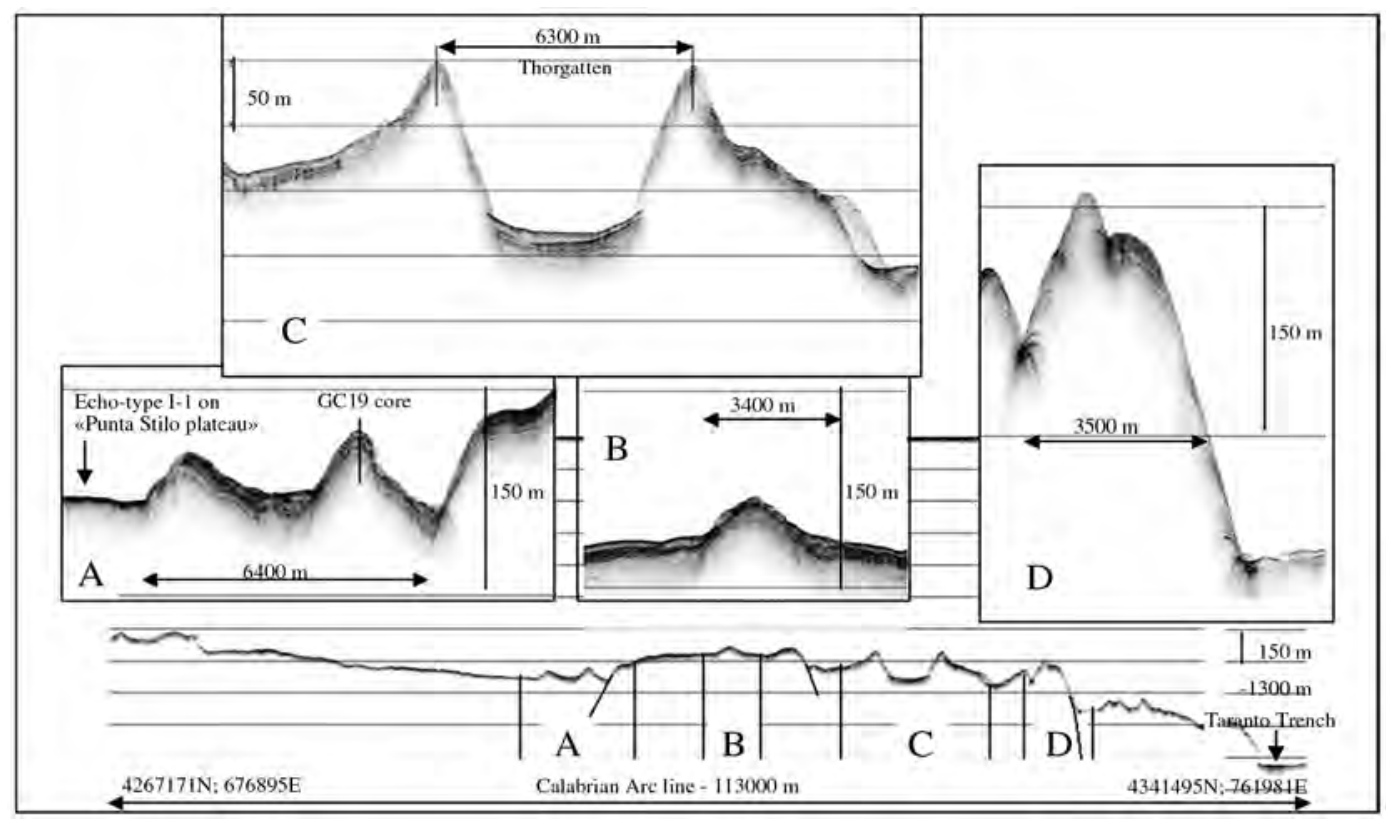

Fig. 4. Chirp profile across the Calabrian margin (Calabrian Arc line - see fig. 1 for location), with the zoom of the main geophysical features that could be related to mud volcanism (A, B, C, D). A - Two mounds with asymmetric flanks mantled by sediments, characterised by slumpings with the location of the GC-19 core (see fig. 1 for location). B - Isolated symmetric mound with chaotic sediment, with the ring shaped depression filled by re-deposited sediments surrounding the volcano, that is a typical character of mud cones. $\mathrm{C}-$ the U-shaped valley (Thorgatten), with sub-horizontal reflectors on the flat bottom, bordered by two acoustically transparent mounds, interpreted as mud volcanoes. D - Particular in rough topography area of a transparent symmetric mound at the top of a horst (interpreted as mud volcano). 
out of reflectors below the sea bottom, suggesting lobate and basin-fill geometry of deposits (Merlini, pers. comm.). The origin of sediments involved in turbidites is probably the steep continental margin off-shore Calabria.

\subsubsection{Geophysical evidence of mud volcanism}

Several transparent mounds, 100-150 m high and from $2000 \mathrm{~m}$ to $3500 \mathrm{~m}$ across, have been identified. They occur in small groups of two or three elements and in many cases they present asymmetric flanks; they can be mantled by sediments, sometimes characterised by slumpings (fig. 4). Dimensions of the mounds are consistent with the mud volcanoes and mud cones identified on the Mediterranean ridge (Camerlenghi et al., 1992, 1995; Limonov et al., 1994; Fusi and Kenyon, 1996 among others). Two of these mounds were investigated by a detailed survey, that included sampling. Core GC 19, taken on top of one mound (fig. 1), recovered only soft mud, alternated with a tephra layer and some sandy layers; it can thus be inferred that the mud breccia, if present, is buried below several meters of layered sediments, as suggested by reflectors on top of the mound.

A peculiar morphologic and seismic feature of this area is an U-shaped valley, here called Thorgatten, about $130 \mathrm{~m}$ deep (fig. 4); sub-horizontal reflectors can be seen on its flat bottom, about $3.5 \mathrm{~km}$ wide. It is bordered by two acoustically transparent mounds, interpreted as mud volcanoes, presenting steep internal flanks, whereas the outer flanks are characterised by dipping reflectors sometimes chaotic, due to slumping. The Thorgatten lies on the outcrop of the minor southwestward verging thrusts, identified on CROP line M5. A similar relationships between mud volcanoes and compressive deep tectonics has been delineated on the Mediterranean ridge $(\mathrm{Ca}-$ merlenghi et al., 1995).

Although we did not observe any chimney cross cutting the sedimentary sequence below the mud volcanoes, we did observe (fig. 4) a typical character of mud volcanoes worldwide, that is the ring shaped depression filled by re-deposited sediments surrounding the volcano (see fig. 15 of Camerlenghi et al., 1995).
The presence of mud volcanoes on the Calabrian ridge was already known: some few small isolated mud cones were identified by means of a discontinuous side scan sonar survey (GLORIA; Fusi and Kenyon, 1996); they have a round shape and seem to recur as isolated spots, whereas on the Mediterranean ridge mud volcanoes are found in groups, of different shapes and dimensions, on the northern edge of the ridge (Camerlenghi et al., 1992, 1995; Limonov et al., 1994; Fusi and Kenyon 1996); mud volcanoes on the Calabrian ridge are generally smaller than those on the Mediterranean ridge (see fig. 3 of Fusi and Kenyon, 1996). On the basis of GLORIA data (Fusi and Kenyon, 1996) it can be hypothesized that most mud volcanoes on the Calabrian ridge are circular or sub-circular, but it cannot be excluded that some of them, especially those located along thrust planes, such as Thorgatten, are mud ridges.

\subsection{Taranto Trench}

The Taranto Trench appears as an almost symmetrical depression (fig. 1), about $2500 \mathrm{~m}$ deep (fig. 5) and about $9.5 \mathrm{~km}$ wide; both NE and SW slopes of the trench have the same gradient (about $18^{\circ}$ ). Its axis, which follows the outcropping of the accretionary wedge front, has an apenninic direction (NNW-SSE) in this part of the Ionian Sea. Along its axis, the topography of the Taranto Trench is characterised by two main steps of about $200 \mathrm{~m}$ each at $2800 \mathrm{~m}$ and $2700 \mathrm{~m}$ depth (fig. 6). The deepest part of the line is characterized by sharp surface echo, with no sub-bottom reflectors, referred to echo type I- 1 . The flat area starting after the second steps, from $2600 \mathrm{~m}$ to $2400 \mathrm{~m}$ depth shows two main characteristics: a) reflectors, generally mantling the topography but in some cases pinching out on small mounds; b) small basins, about $1 \mathrm{~km}$ wide and $50 \mathrm{~m}$ deep, filled up by about $20 \mathrm{~m}$ of sediments. The upper part of the trench is characterised by a hummocky topography with some chaotic reflectors, referable to echo type IV-3, interpreted as interlayered debrites and turbidites.

As for the Punta Stilo plateau, we suggest that the Taranto Trench is filled by coarse grained turbidites; reflectors identified on CROP 


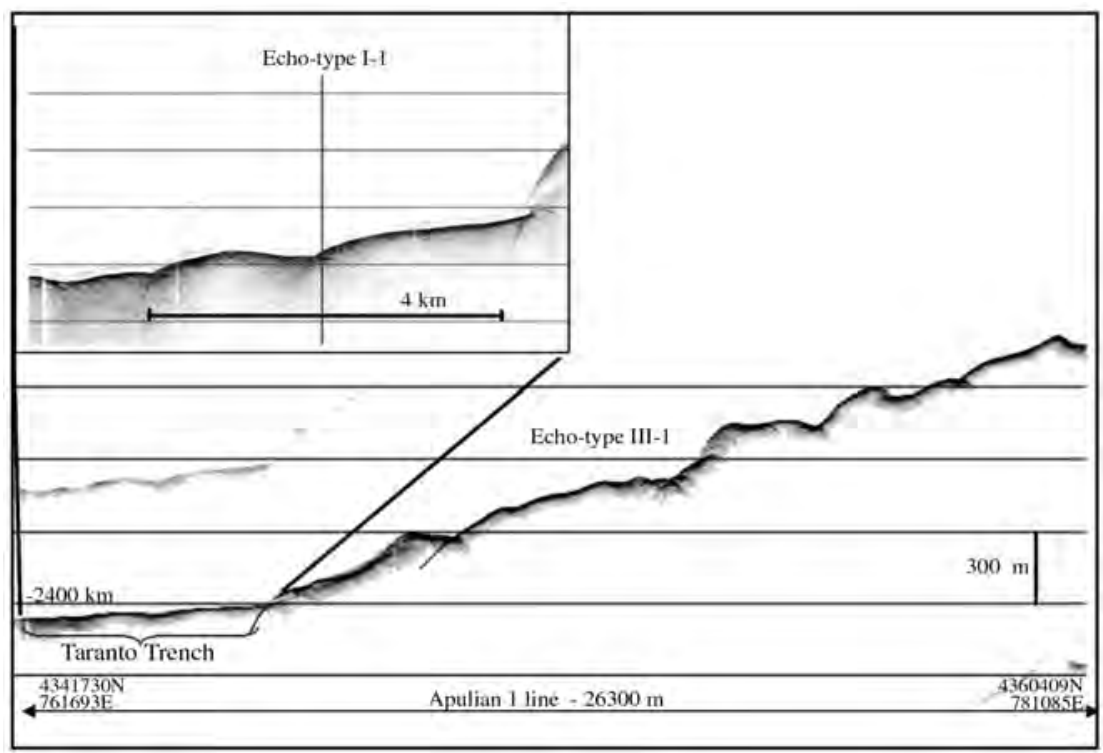

Fig. 5. Chirp profile across the Taranto Trench and the eastern section of Apulian plateau (Apulian 1 line - see fig. 1 for location), that rises through westward dipping deep seated faults. The zoom shows the sharp surface echo, with no sub-bottom reflectors, that characterised the Taranto Trench.

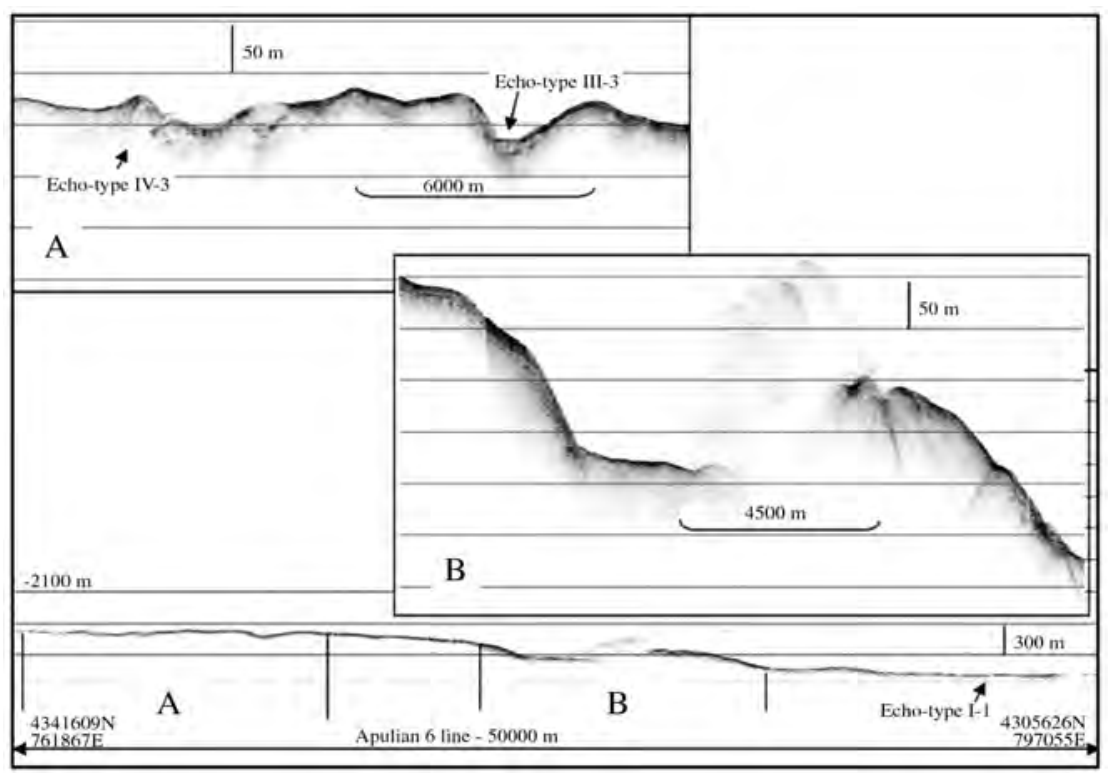

Fig. 6. Chirp profile across the axis of Taranto Trench (Apulian 6 line - see fig. 1 for location), with the zoom of the main features identified (A, B): A - a hummocky topography with some chaotic reflectors and small basins filled up by sediments; B - the deepest part of the trench with steplike topography. 
seismic line M5 in the Taranto Trench, which onlap the Apulian platform, suggest different turbiditic episodes. Turbidity currents, probably originating from the inner parts of the Taranto Gulf, are channelled along the Taranto Trench axis, eroding in part former deposits and filling small basins.

\subsection{Apulian plateau}

The Apulian plateau rises from more than $2400 \mathrm{~m}$ to about $200 \mathrm{~m}$ depth through several westward dipping deep seated faults, with a total throw of about $1500 \mathrm{~m}$, also affecting the sea-bottom. Merlini et al. (2000) tentatively interpret these south-western scarps on the Apulian plateau as an example of foreland inversion and thus they hypothesise two thrust planes (fig. 5 of Merlini et al., 2000). On chirp we have no evidence of such faults.

Few probable mud volcanoes were identified on the slope toward the Taranto Trench and are probably related to these deep seated structures. In this area the seismic signal has no penetration, due to the steepness of relief. The diffuse presence of irregular overlapping hyperbolae (echo type III-1) prevents identifications of the regional westward dipping monocline visible on CROP line M5.

At about $500 \mathrm{~m}$ depth, three antiforms can be recognised on chirp profiles (figs. 7 and 8); their axis is appeninic (NNW-SSE) and parallel to the main dip slip faults of the Apulian Plateau. The first one from SW is the more evident, both from bathymetry and from seismics. The chirp survey suggests an asymmetric antiform, with its NE flank mantled by reflectors, $50 \mathrm{~ms}$ thick, onlap-

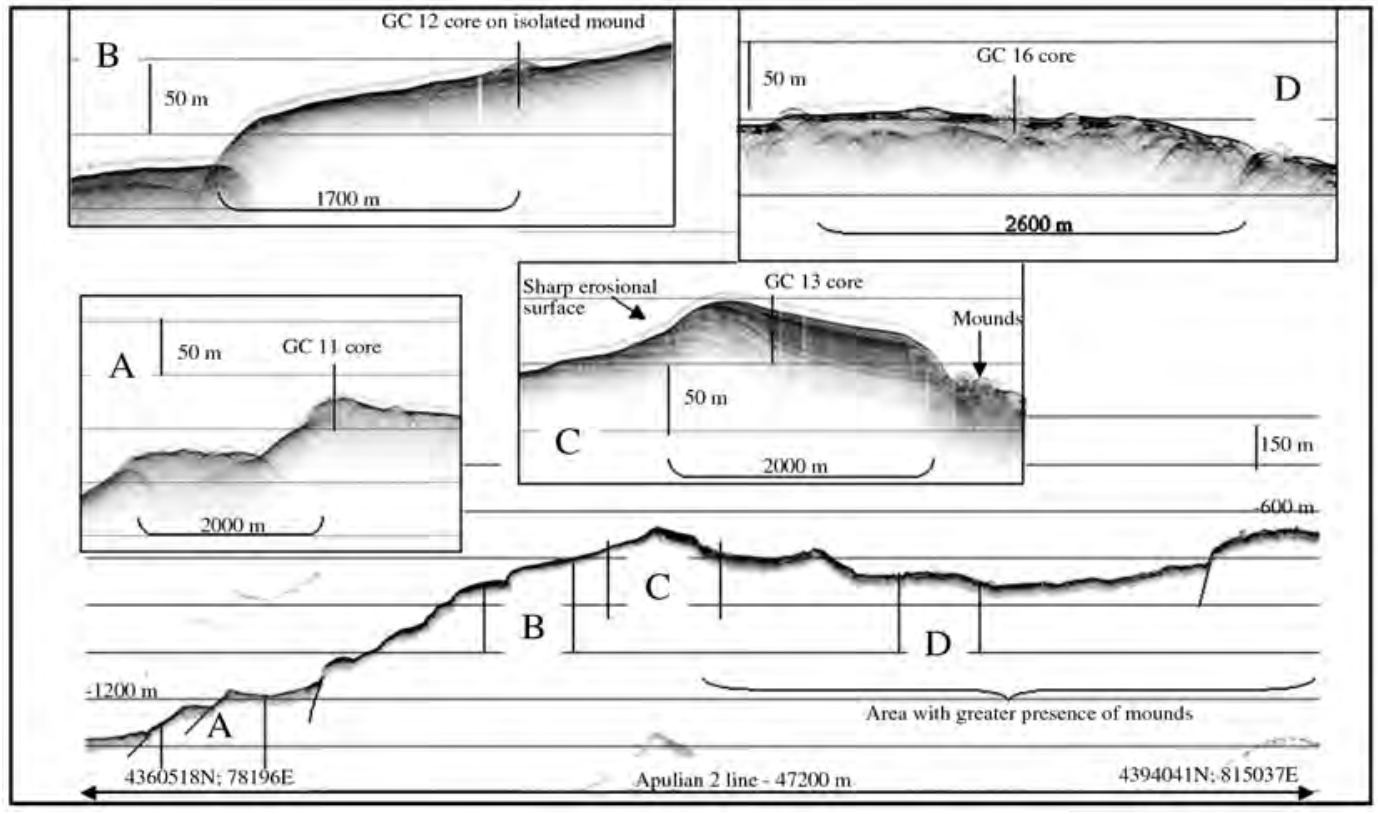

Fig. 7. Chirp profile across the Apulian plateau (Apulian 2 line - see fig. 1 for location), with the insets (A, B, $\mathrm{C}, \mathrm{D})$ of the main tectonic and geophysical features that mark the transparent mounds recognised in this area and the location of the main cores collected. A - Group of transparent mounds on the top of the fault steps; B - isolated transparent mound on a fault step; $\mathrm{C}$ - the asymmetric antiform, with the NE flank mantled by reflectors, onlapping the crest of the structure, and the south-western flank characterised by sub-horizontal reflectors, truncated by a sharp erosional surface; D - area with widespread transparent mounds and ponded sediments. 


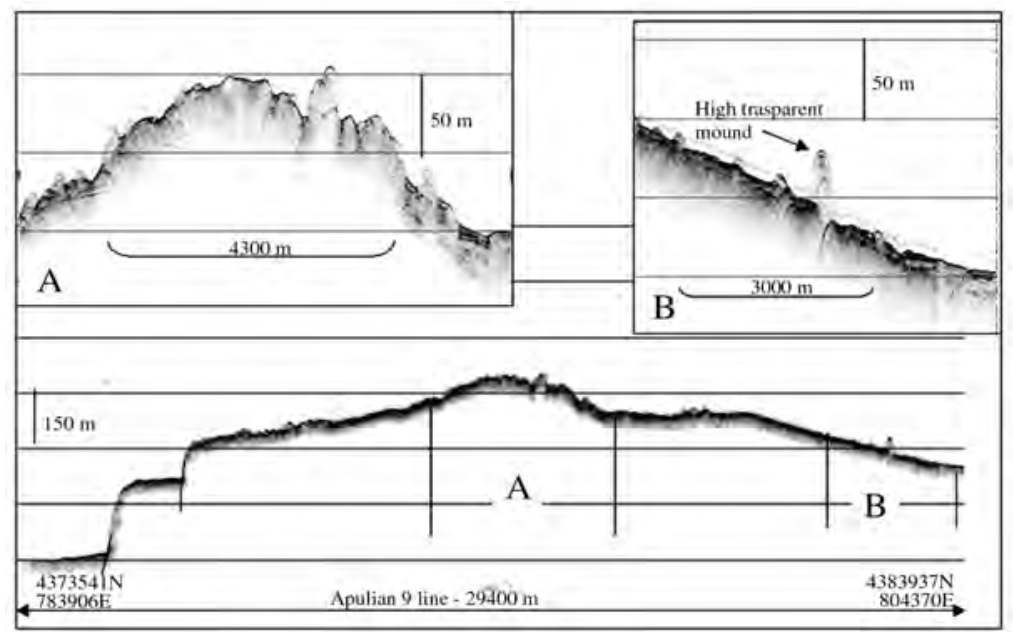

Fig. 8. Chirp profile across the Apulian plateau (Apulian 9 line - see fig. 1 for location), with the zooms (A, B) of the main geophysical features that characterise the mound fields recognised in this area. See on zoom B the highest transparent mound identified on Apulian plateau.

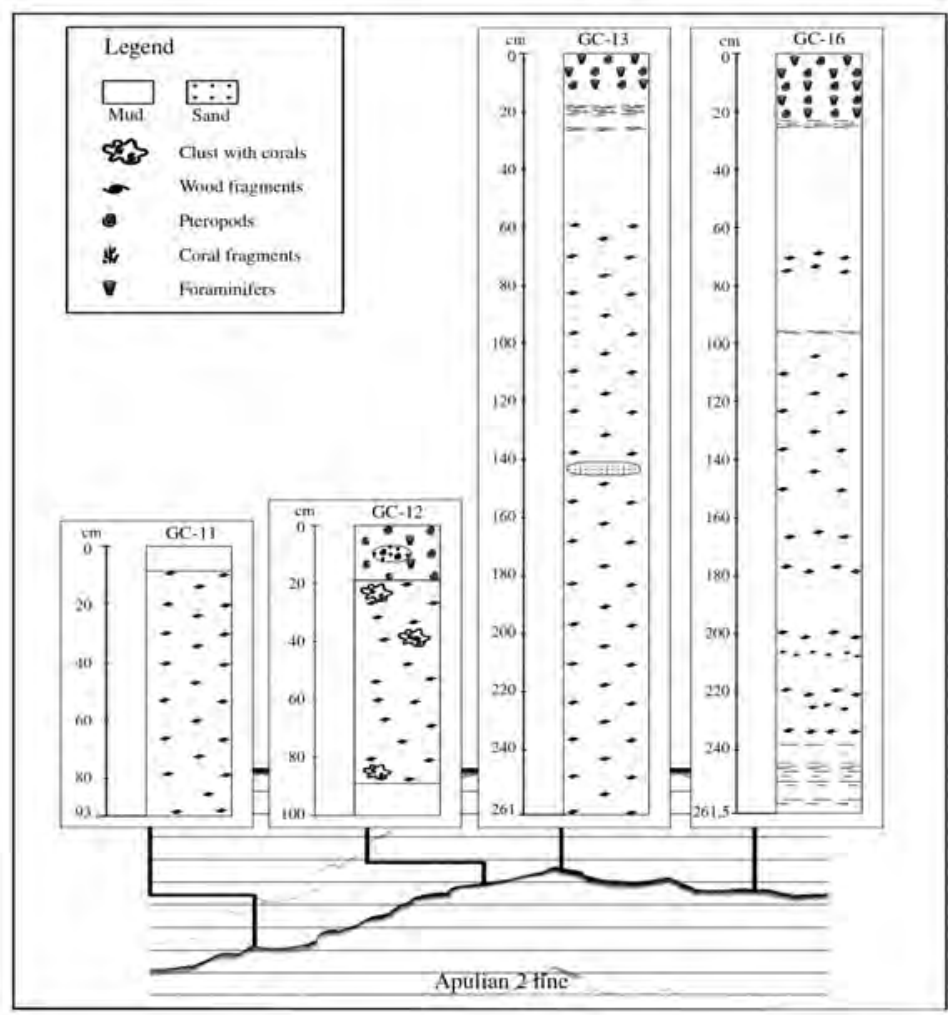

Fig. 9. Log of cores GC 11, GC 12, GC 13, and GC 16 (see figs. 1 and 7 for location). 


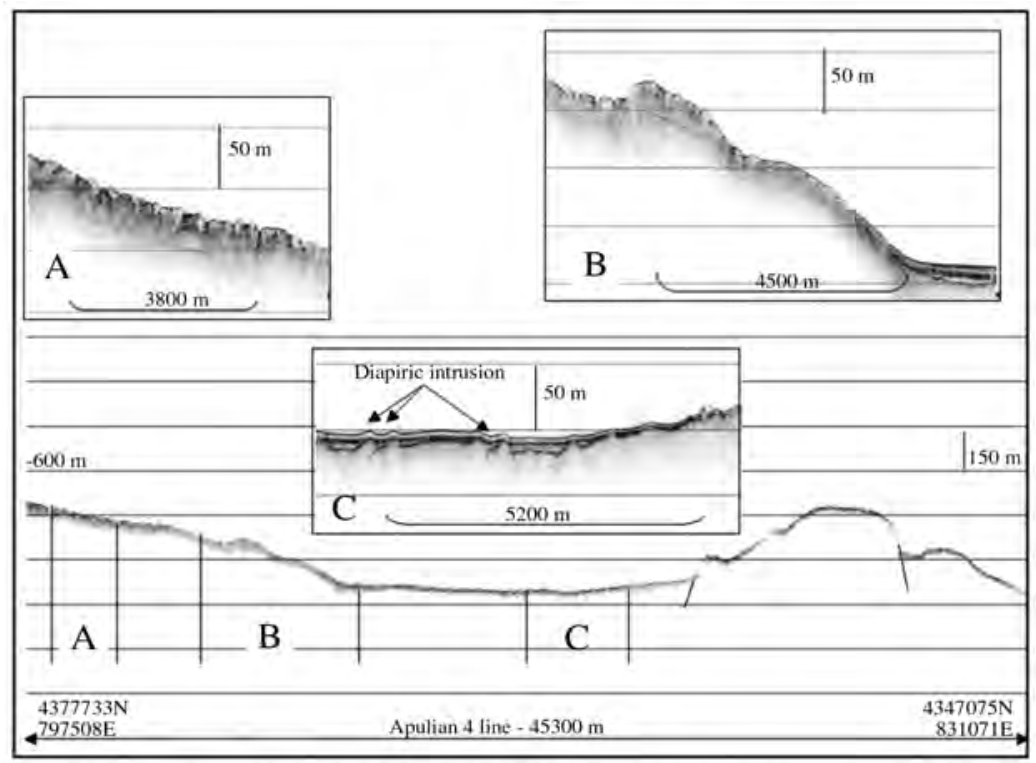

Fig. 10. Chirp profile across the Apulian plateau (Apulian 4 line - see fig. 1 for location), with the zooms of the main geophysical features that characterise the mound fields recognised in this area (A, B) and the diapiric intrusions $(\mathrm{C})$.

ping the crest of the structure and probably disrupted by a normal Apenninic fault, which could be interpreted as a conduit for fluid expulsion (see 3.4.1). The south-western flank of this structure presents sub-horizontal reflectors, truncated by a sharp erosional surface at about $750 \mathrm{~m}$ depth; the outcrop or subcrop of old consolidated sedimentary successions can be reasonably supposed. On the top of this anticline small reverse faults were identified, suggesting a recent activity of this structure. This structure (figs. 7 and 8) can be recognised also on CROP line M5, where it is underlined by two reverse faults which isolate a wedge, extruded upward. These reverse faults seem to affect both the Mesozoic Apulian Carbonate platform and the NeogenePleistocene sediments (fig. 6 of Merlini et al., 2000).

A gravity core taken at the top of this anticline structure (GC 13, $666 \mathrm{~m}$ depth) recovered $261 \mathrm{~cm}$ of mud, stiffer toward the bottom of the core, with pteropod fragments and foram tests in the upper $13 \mathrm{~cm}$ (fig. 9). This structure is followed to the NE by two other antiforms, less ev- ident from their morphology, but still identifiable by seismics (fig. 8).

On the basis of chirp data we interpret both the three anticlines and the reverse faults as minor structures, ductile and tensile respectively, connected to the Apulian lithospheric anticline.

On the Apulian plateau an erosional surface at about $900 \mathrm{~m}$ depth is cut by several diapiric structures, sometimes crosscutting each other, and covered by a transparent sedimentary interval, which is thinner on structural highs and thicker in small basin (fig. 10). Some strong reflectors, thicker north-westward, mantle some of the diapiric structures; they are reduced southeastward to one single reflector, which is cut by the diapiric structures. A semi transparent sedimentary interval mantles all the diapiric structures, onlapping south-eastward on the swelling of a nearby horst structure. In analogy with the other transparent mounds, these structures are interpreted as sub-cropping mud diapirs, deforming all the sedimentary sequence. Their intrusion is thus interpreted as an actual deformation structure, since it offsets the sea bottom; as- 
suming this hypothesis, the sediment deformation rate is higher than the sedimentation rate.

\section{Geologic and structural interpretation of the study area}

A synthetic structural-geological map and a cross section of the study area were produced (figs. 11 and 12) on the basis of: a) the echo characters and shallow structures identified on chirp survey; b) core logs collected as ground truth data; c) deeper seismics (CROP line M5) and its structural interpretation.
The transition between the extensional tectonics of the Calabrian margin and the compressive tectonics of the accretionary wedge is represented by the Punta Stilo plateau (figs. 11 and 12), dominated by the sedimentation of coarse grained turbidites and not affected yet by active tectonics. This plateau can be interpreted as a sort of huge talus, which collect coarse sediments, deriving from the erosion and mass movements from the steep Calabrian margin and from the main land.

The accretionary wedge, marked to the front by an eastward verging thrust, is topographically and structurally deeper than the foreland and

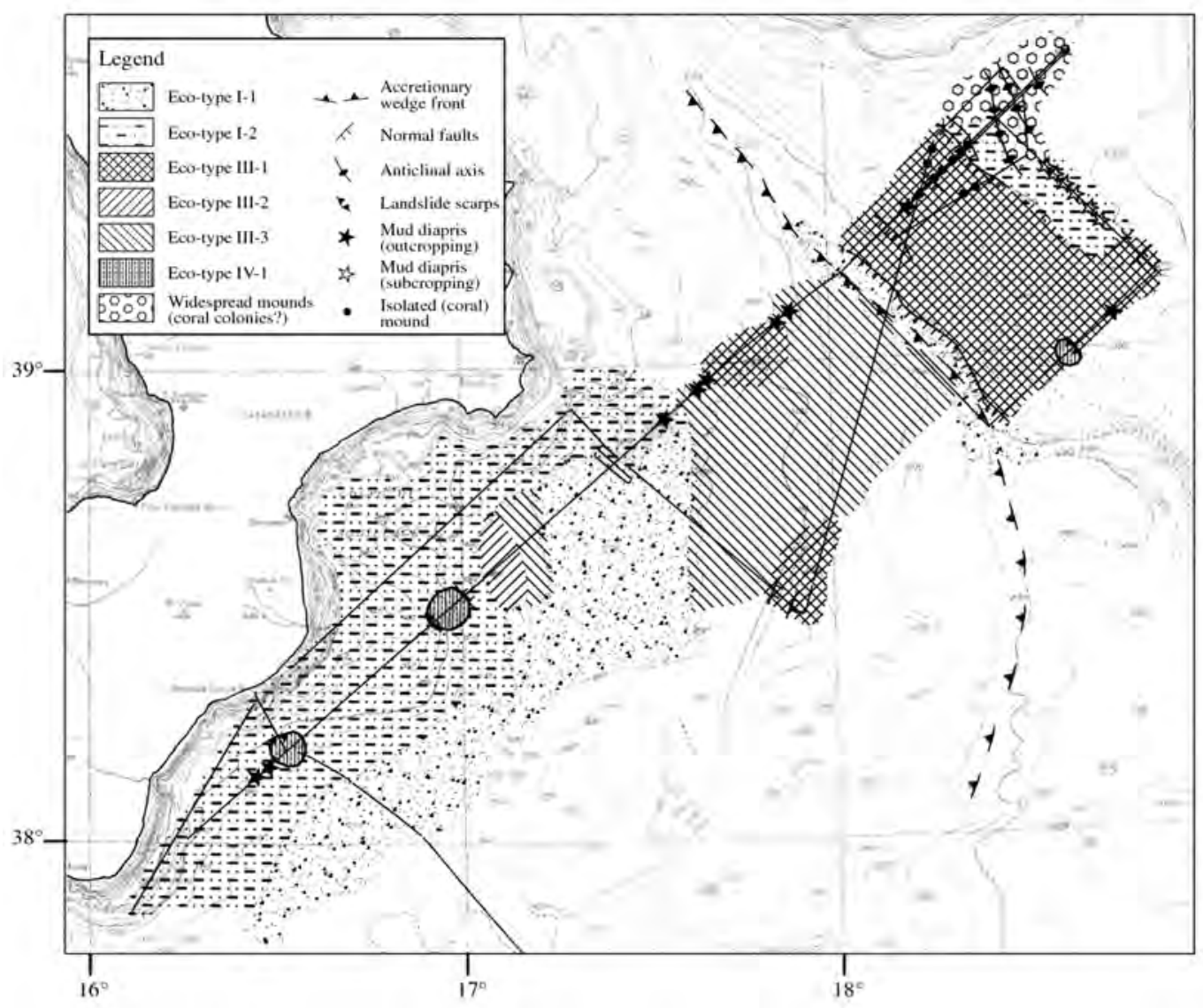

Fig. 11. Synthetic structural-geological map of the Northern Ionian Sea produced on the basis of the echo characters and shallow structures identified on chirp survey and the core logs. 


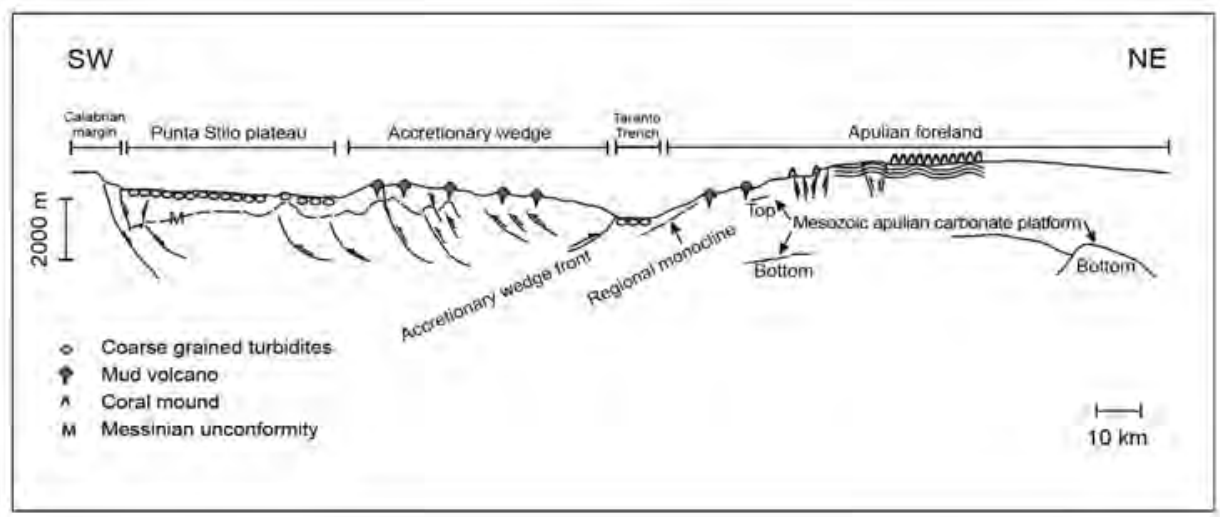

Fig. 12. Cross section of the Northern Ionian Sea with shallow tectonics structures identified by chirp survey, related to deeper ones from Doglioni et al. (1999) and Merlini et al. (2000).

is mainly subsiding (Doglioni et al., 1999; Merlini et al., 2000). On chirp profiles there is no sign of the compressive tectonics identified on CROP line M5 and in particular of the accretionary wedge front, but the widespread presence of creep deposits and debrites suggests a recent activity of this area.

The Apulian foreland, separated from the accretionary wedge by the narrow Taranto Trench, filled up by coarse turbidites, is folded by a 100 $\mathrm{km}$ wide crustal-lithospheric anticline, currently uplifting (Merlini et al., 2000). Superficial anticlinal folds and reverse faults identified on chirp profiles (figs. 7, 11 and 12) are interpreted as minor tensional and ductile compressive structures, connected with the hinge zone of the Apulian lithospheric anticline.

In the study area mud volcanoes do not seem to be related to any particular geodynamic context, since they occur both on the accretionary wedge and on the margin of the Apulian foreland (see 4.4.2). This difference from the Mediterranean rigde, where deep origin mud volcanoes occur only at the NE edge of the ridge due to reduced thickness of Messinian evaporites and to the presence of thrusts (Camerlenghi et al., 1995) suggests that: a) the source rock is not as deep as on the Mediterranean ridge or there are possibly different source rocks at different depths; in fact, according to well $\operatorname{logs}$ (Merlini, pers. comm.), different age clays are widespread in all this area; b) mud diapris are related to deep seated tectonic structures, such as thrusts and/or dip slip faults. c) Messinian evaporites are absent or highly reduced in thickness, as suggested both by well logs on the mainland (Casero, 2004) and seismic sections, where a Messinian unconformity can be traced on the Calabrian margin and on the accretionary wedge (Doglioni et al., 1999; Merlini et al., 2000). In the Ionian sea the only deep well drilled (ODP Site 964 on the Pisano plateau) recovered $112 \mathrm{~m}$ of Plio-Pleistocene nannofossil ooze (Shipboard Scientific Party, 1996), adding no further information to the presence/absence of evaporites.

\section{Geophysical evidence of coral mounds}

The Apulian plateau is characterised by the widespread presence of transparent mounds, about $20 \mathrm{~m}$ high and 200-300 m large each; they occur as isolated mounds on the top of the fault steps in the deepest zones $(1600-800 \mathrm{~m}-$ fig. 7$)$ and become widespread from $800 \mathrm{~m}$ depth up, both in groups and as single mounds separated by reflectors. In some areas the mounds are underlined by concave downward reflectors, repeating the morphology of the mounds themselves. A particularly high (about $50 \mathrm{~m}$ ) transparent mound was identified at a depth of about 750 $\mathrm{m}$ (fig. 8). Three gravity cores have been collected on these mounds (figs. 1 and 7). Core GC 11, taken on a fault step with a transparent mound, at 
$1170 \mathrm{~m}$ depth recovered only $93 \mathrm{~cm}$ of brown mud. Core GC 12 (800 m depth), taken on an isolated transparent mound, and core GC 16 (750 $\mathrm{m}$ depth), taken in the area of widespread transparent mounds, recovered respectively: 100 $\mathrm{cm}$ of grey mud with forams and pteropods at the top and coral fragments in the upper $40 \mathrm{~cm} ; 341$ $\mathrm{cm}$ of mud, with forams and pteropods at the top (fig. 9).

These mounds are here interpreted as coral mounds, on the basis of their acoustic and morphological characters. In fact, due to the high reflectivity at their top, reef structures mask the acoustic response further down, appearing thus transparent. Furthermore, these transparent mounds rise from the sea bed with a relatively high angle, that is about $50^{\circ}$, as described also for Norwegian reefs (Hovland and Thomsen, 1997). Seismic data are supported by the recent discovery in this area of dredged living corals (Tursi and Mastrototaro, pers. comm.) and of coral fragments in core GC 12.
Hovland and Thomsen (1997) proposed that the presence of cold deep water coral could be associated with microseepage from the seabed of light hydrocarbons which provide nutrients for bioconstructor organisms. Coral colonies become widespread from the apenninic dip slip fault disrupting the anticline (fig. 7); this part of the Apulian plateau is intensively fracturated by conjugate dip slip faults affecting the NeogenePleistocene sedimentary sequence (Merlini et al., 2000) and providing a local micro-seepage through the seabed of light hydrocarbons, useful for the life of cold water corals (Hovland and Thomsen, 1997).

The areal extension and shape of coral colonies is currently unknown. On the basis of our survey, the area characterised by the presence of coral mounds should cover about $250 \mathrm{~km}^{2}$. In any case, this coral site on the Apulian plateau seems to be one of the more extended and richer deep water coral site of the Mediterranean Sea and is worth additional detailed investigations.
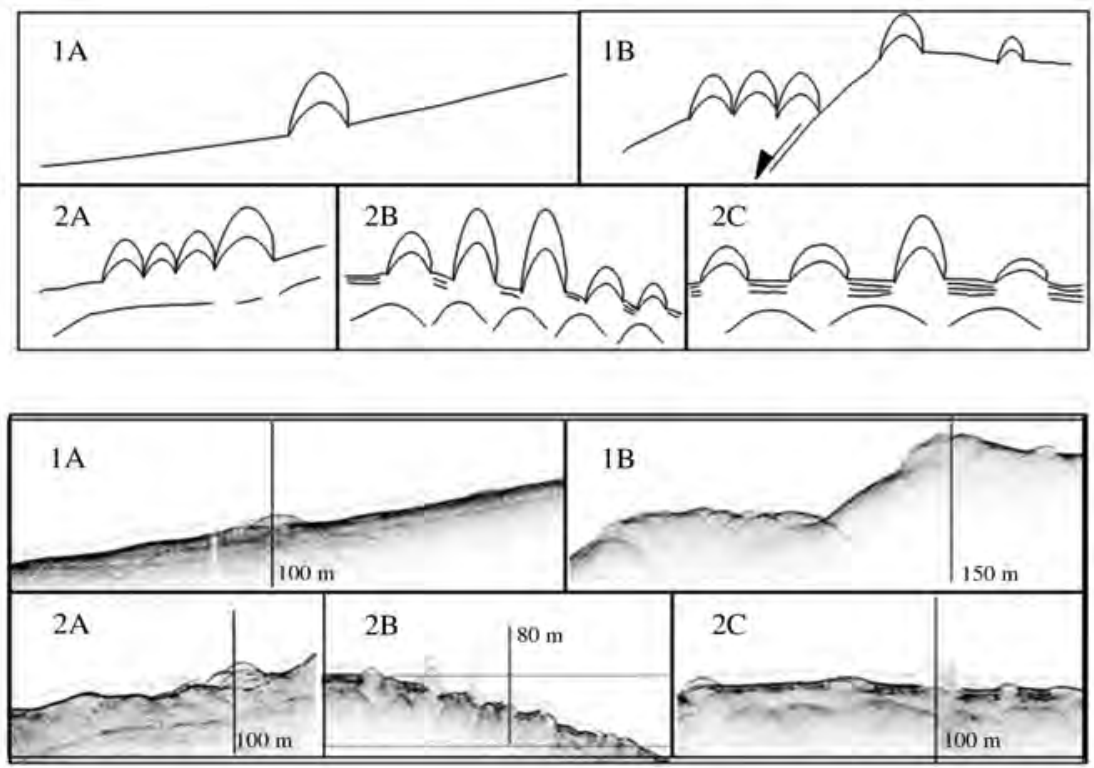

Fig. 13. Different scenarios of the geophysical evidence of transparent mounds identified on the Apulian plateau: $1 \mathrm{~A}$ - isolated mounds, located on the slopes; $1 \mathrm{~B}$ - small groups near the main dip slip fault steps; $2 \mathrm{~A}$ - widespread mounds, cross cutting each others, below which no reflector can be detected; $2 \mathrm{~B}$ - widespread mounds, cross cutting each others, underlined by upward convex reflectors; $2 \mathrm{C}$ - small mounds separated by ponded sediments. 
According to our survey coral mounds are present in two main different scenarios (fig. 13):

1) On the slope of the Apulian swell rising from the Taranto Trench, in water depth as deep as $1600 \mathrm{~m}$, coral mounds occur as: a) isolated mounds, located on the slopes; in this case no deep structure can be reliably connected with biohermes and probably these bio-constructions can be seen as a sort of pioneer organisms; b) small groups of several bioconstructions; their presence is strictly related to the dip slip fault steps, which offset the slope of the Apulian swell in this area. We infer that the presence of coral reefs at this water depth is connected to fluids rising along faults and providing a food source for suspensionfeeders, such as corals (Hovland and Thomsen, 1997).

2) In the shallower part of the Apulian plateau, from about 700 to $400 \mathrm{~m}$ water depth, coral mounds are widespread, covering an area of at least $250 \mathrm{~km}^{2}$; furthermore, coral reefs are located immediately above a nearly surfacing up-dipping and high-reflective layer, that can be interpreted as partly gas charged and an upward micro-seepage site (Hovland and Thomsen, 1997). They can occur as: a) groups of several tens of high reflective mounds, cross cutting each other, below which no reflector can be detected. Due both to concentration of reefs and to their particular height (up to $50 \mathrm{~m}$ ) we interpret this scenario as characterised by fast growing bio-constructions; b) groups of several tens of high reflective mounds, cross cutting each other, underlined by upward convex reflectors, interpreted as dead coral reefs. This context suggests superimposed cycles of biohermes; it can thus be inferred that the presence of corals in this area is long lasting; c) small coral mounds, few meters high, separated by ponded sediments; one of this coral reefs grows on one small fault, offsetting the sea bottom, with a throw of about $3 \mathrm{~m}$. We interpret this situation as isolated, relatively slow growing bioconstructions, separated by ponded sediments.

\section{Conclusions}

The peculiarity of the study area is the passage from an extensional tectonic regime (Calabrian margin) through a compressive one (Cal- abrian ridge) to a stable zone (Apulian foreland). The main results of our chirp survey in this area are the following:

1) The transition between the extensional tectonics of the Calabrian margin and the compressive tectonics of the accretionary wedge is represented by a wide flat plateau (Punta Stilo plateau), gently dipping south-eastward $\left(0.2^{\circ}\right)$ and dominated by the sedimentation of coarse grained turbidites; no evidence of active tectonics can be identified on this plateau.

2) Superficial anticlinal folds and reverse faults, identified on the Apulian plateau, are interpreted as minor tensional and ductile compressive structures, connected with the hinge zone of the Apulian lithospheric anticline.

3) Some mud volcanoes have been identified in the whole study area. In analogy with what has been observed on the Mediterranean ridge, their presence suggests the activity of deep tectonic structures (both thrusts and faults) and/or a reduced thickness (or absence) of Messinian evaporites in this part of the Ionian Sea.

4) On the Apulian plateau, the widespread presence of mounds, up to $50 \mathrm{~m}$ high, occurring as isolated mounds in the deepest zones (1600$800 \mathrm{~m})$ and in groups in the shallower ones (800-600 m), has been interpreted as deep water coral bioconstructions, according to a recent discovery of living deep corals in this zone. The intense fracturation of the Apulian plateau and the possible related cold seepage of hydrocarbons could sustain the deep coral communities through the presence of chemiosyntetic bacteria as primary producers.

\section{Acknowledgements}

Authors are grateful to Saverio Merlini for constructive discussions. Angelo Camerlenghi kindly revised the first draft of the manuscript.

\section{REFERENCES}

Amato, A. and G. SelvagGi (1993): Aftershock location and $\mathrm{p}$-wave velocity structure in the epicentral region of the 1980 Irpinia earthquake, Ann. Geofis., XXXVI (1), 3-15.

Boccaletti, M., N. Ciaranfi, D. Cosentino, G. Deiana, 
R. Gelati, F. Lentini, F. Massari, G. Moratti, T. Pescatore, F. Ricci LuCChi and L. Tortorici (1990): Palinspastic restoration and paleogeographic reconstruction of the peri-Tyrrhenian area during the Neogene, Paleocl., Paleoec., Paleogeog., 77, 41-50.

Camerlenghi, A., M.B. Cita, W. Hieke and T.S. RicchiUTO (1992): Geological evidence of mud diapirism on the Mediterranean ridge accretionary complex, Earth Planet. Sci. Lett., 109, 493-506.

Camerlenghi, A., M.B. Cita, B. Della Vedova, N. Fusi, L. Mirabile and G. Pellis (1995): Geophysical evidence of mud diapirism on the Mediterranean ridge accretionary complex, Mar. Geophys. Res., 17, 115-141.

Casero, P. (2004): Structural setting of petroleum exploration plays in Italy, in Geology of Italy, edited by U. Crescenti, S. D'Offizi, S. Merlino and L. SaCCHI, Spec. Vol. Ital. Geol. Soc. for the IGC 32, 189-199.

Cristofolini, R., F. Ghisetti, R. Scarpa and L. Vezzani (1985): Character of the stress field in the Calabrian Arc and the Southern Apennines (Italy) as deduced by geological, seismological and volcanological information, Tectonophysics, 117, 39-58.

DAmuTH, J.E. (1980): Use fo high-frequency (3.5-12 kHz) echograms in the study of near-bottom sedimentation processes in the deep-sea: a review, Mar. Geol., 38, $51-75$.

DAMUth, J.E. and D.E. HAYES (1977): Echo character of the East Brazilian continental margin and its relationship to sedimentary processes, Mar. Geol., 24, 73-95.

DoGLIONI, C. (1991): A proposal of kinematic modelling for $W$-dipping subductions: possibile applications to the Tyrrhenian-Apennjnes system, Terra Nova, 3, 423-434.

Doglioni, C., F. Mongelli and P. Pieri (1994): The Puglia uplift (SE Italy): an anomaly in the foreland of the Apenninic subduction due to buckling of a thick continental lithosphere, Tectonics, 13 (5), 1309-1321.

Doglioni, C., P. Harabaglia, G. Martinelli, F. MongelLI and G. ZiTo (1996): A geodynamic model of the Southern Apennines, Terra Nova, 8, 540-547.

Doglioni, C., S. Merlini and G. Cantarella (1999): Foredeep geometries at the front of the Apennines in the Ionian Sea (Central Mediterranean), Earth Planet. Sci. Lett., 168: 243-254.

Fusi, N. and N.H. KENYON (1996): Distribution of mud diapirism and other geological structures from longrange sidescan sonar (GLORIA) data, in the Eastern Mediterranean Sea, Mar. Geol., 132, 21-38.

Gasparini, C., R. Scarpa and L. Vezzani (1982): Seismotecotnics of the Calabrian Arc, Tectonophysics, 84, 276-286.

Hovland, M. and E. Thomsen (1997): Cold-water corals -
Are they hydrocarbon seep related?, Mar. Geol., 137, 159-164.

LeE, S.H., S.K. Chough, G.G. Back and Y.B. Kim (2002): Chirp $(2-7 \mathrm{kHz})$ echo characters of the South Korea plateau, East Sea: styles of mass movement and sediment gravity flow, Mar. Geol., 184, 227-247.

Limonov, A.F., J.M. WoOdsidE and M.K. Ivanov (Editors) (1994): Mud volcanism in the Mediterranean and Black seas and shallow structure of the Eratosthenes seamount, in Initial Results of the Geological and Geophysical Investigation during the third UNESCO-ESF "Training Through Research» Cruise of R/V, June-July 1993, Gelendzhik, UNESCO Rep. Mar. Sci., 64, pp. 173.

MalinVerno, A. and W.B.F. RyAn (1986): Extension in the Tyrrhenina Sea and shortening in the Apennines as a result of arc migration driven by sinking of the lithosphere, Tectonics, 5, 227-245.

Merlini, S., G. Cantarella and C. Doglioni (2000): On the seismic profile Crop M5 in the Ionian Sea, Boll. Soc. Geol. Ital., 119, 227-236.

Mostardini, F. and S. Merlini (1986): Appennino CentroMeridionale. Sezioni Geologiche e Proposta di Modello Strutturale (Agip), p. 59.

Patacca, E. and P. ScAndone (1989): Post-Tortonian mountain building in the Apennines. The role of the passive sinking of a relic lithosphere slab, in The Lithosphere in Italy, edited by A. Boriani, M. BonAFEDE, G.B. PicCARDO and G.B. VAI, Acc. Naz. Lincei, Atti dei Convegni Lincei, 80, 157-176.

Patacca, E. and P. Scandone (2004): The Plio-Pleistocene thrust belt - Foredeep system in the Southern Apennines and Sicily (Italy), in Geology of Italy, edited by U. Crescenti, S. D’OfFizi, S. Merlino and L. SACChi, Spec. Vol. Ital. Geol. Soc. for the IGC 32, 93-129.

PAtAcCA, E., R. SARTORI and P. ScAndone (1990): Tyrrhenian Basin and Apenninic arcs, kinematic relations since late Tortonian times, Mem. Soc. Geol. Ital., 45, 425-451.

Royden, L., E. Patacca and P. Scandone (1987): Segmentation and configuration of subducted lithosphere in Italy: an important control on thrust-belt and foredeepbasin evolution, Geology, 15, 714-717.

Sella, M., C. TuRCI and A. Riva (1988): Sintesi geopetrolifera della fossa Bradanica, Mem. Soc. Geol. Ital., 41, 87-108.

Selvaggi, G. and C. Chiarabba (1995): Seismicity and pwave velocity image of the Southern Tyrrhenian subduction zone, Geophys. J. Int., 121, 818-826.

Shipboard Scientific Party (1996): Site 964, Proceedings of the Ocean Drilling Program, Init. Rep. (College Station TX, Ocean Drilling Program), 160, 85-123. 